\title{
Pod Characteristics of Cocoa (Theobroma cacao L.) Related to Cocoa Pod Borer Resistance
}

\author{
Agung Wahyu Susilo ${ }^{1 *}$, Surip Mawardi ${ }^{1)}$, Witjaksono ${ }^{2)}$, and Woerjono Mangoendidjojo ${ }^{2)}$ \\ 1) Indonesian Coffee and Cocoa Research Institute, J1. PB. Sudirman 90, Jember Indonesia \\ ${ }^{2)}$ Agriculture Faculty, Gadjah Mada University, Bulaksumur, Yogyakarta 55281 Indonesia \\ ${ }^{*}$ Corresponding author: soesiloiccri@yahoo.com
}

\begin{abstract}
The characteristics of cocoa (Theobroma cacao L.) pod related to cocoa pod borer resistance (CPB) had been identified in a series of study. The objective of this research is to evaluate the characteristics of cocoa pod using more diverse of genetic background to obtain selection criteria. Genetic materials for this study were 25 cocoa clones planted in Central Sulawesi for resistance evaluation. Field evaluation of the resistance were assessed by using variable of the percentage of unextractable beans, number of larvae entry and exit holes by which the clones were grouped into 5 groups of resistance. A laboratory works were carried out to assess pod characteristics based on the number of trichomes, granules of tannin and thickness the lignified-tissue of sclerotic layer using micro-technique method at the different level of pod maturity $(3.0 ; 3.5 ; 4.0$ months). Correlation between groups of those variables was analyzed using canonical correlation. The result performed a positive association between the thickness of sclerotic layer at the secondary furrow with the number of entry holes and the number of entry holes through sclerotic layer. The thickness performed a higher value of the coefficient in association with the variables of canonical for pod characteristics $0.59 ; 0.55$; 0.43 and the variables of canonical correlation for CPB resistance $0.54 ; 0.51 ; 0.39$ that would presenting the characteristics of pod related to CPB resistance in 3.0, 3.5 and 4.0 months of pod maturity. Lignification at sclerotic layer was considered as genotypic expressions due to the thickness at the secondary furrow at 3.0, 3.5 and 4.0 months of pod maturity performed high value of broad-sense heritability i.e. $0.75,0.89$ and 0.92 respectively. A qualitative assessment of the lignification clearly differentiated the resistant clones of ARDACIAR 10 with the susceptible clones of ICCRI 04, KW 516, and KW 564.
\end{abstract}

Key words : cocoa pod borer, Theobroma cacao L., pod characteristics, resistance

\section{INTRODUCTION}

Cocoa pod borer (CPB) is the main pest on cocoa in the Asia-Pacific region which seriously reduce yield potency due to the infected pods cannot be harvested properly that defecting the bean quality. CPB firstly infected cocoa in North Sulawesi last century ago (1860) then spread to Java in the early 1900's (Wardojo, 1980). Intensity of CPB infestation varies among farms depend on how farmers are able to succeed the application on pest management. For controlling the pest it was recommended an integrated management by combining the component of biological control, technical culture and environmental precondition (Sulistyowaty \& Wiryadiputra, 2008). To support the methods, 
some resistant clones were released which be developed by exploring and selecting resistant genotypes through cocoa farms in the endemic area during last ten years (McMahon et al., 2009; Susilo et al., 2012).

Process on selecting CPB-resistant genotypes take time as the resistance has to be confirmed during several periods of harvest time to make sure the resistant expression would not be escaped mechanism. Susilo et al. (2004) reported process on selecting CPB-resistant genotypes by exploring the promising genotypes through population of Upper Amazon Hybrid (UAH) in North Sumatera in where resistant genotypes were confirmed during two years of harvest time. Performance of the resistance was evaluated based on an accumulative assessment of the unextractable beans per harvested pod to present intensity of CPB infestation. Effectiveness on selection using these variables was low (Susilo et al., 2006) due to expression of the resistance still biased with the unstable mobility of imagoes which possibly were affected by environmental condition. To support method on resistant evaluation the number of larvae entry holes pass through mesocarp and the number of larvae exit holes were also abserved (Azhar, 2000) for presenting the activity of larva movement through pod. A positive correlation between the percentages of unextractable beans with the number of larvae entry hole pass through mesocarp was confirmed in the previous study (Susilo et al., 2004) from which the intensity of larva activity could be estimated by the number of entry hole. Further study should be focused on identifying criteria for selection related to characteristics of pod which are able to be assessed easily and genetically expressed.

Identification of the criteria for selection should be based on the characteristics of pod due to the larvae activity mainly on the pods. In the previous study it has been identified some characteristics of pod related to CPB resistance such as trichomes at upper layer of mesocarp, granules of tannin distributed through mesocarp and lignification at the sclerotic layer (Susilo, 2005; Susilo et al., 2007; Susilo et al., 2009). From those studies it can be preliminary concluded the mechanism of CPB resistance may be controlled by both of antixenosis and antibiosis mechanism. The trichomes at upper layer of pod possibly play a significant role on antixenosis by deterring the imagoes hatching on the surface of pod then of the larvae movement through the pod to reach the placental tissue would be suppressed with the tannin compound and lignification at sclerotic layer both act as the chemical or physical barrier. Azhar (2000) and Flood et al. (2004) found more number of laid eggs on rough pod than on smooth pod in which of the rough pod may perform higher density of trichomes. It was reported the clones having lower number of larvae entry holes performing higher number of trichomes and granules of tannin (Susilo et al., 2007; Susilo et al., 2009). It was also identified that the nonlignified tissue (channel) through sclerotic layer more frequent belong to the clones having higher number of larvae exit holes (Susilo, 2005). Further study, Susilo et al. (2007) found significant differences of the lignification among clones which perform different background on CPB resistance. Expressions of the characteristics depend on pod development in which the characteristics were performed maximally during 3.0-4.0 months of pod maturity (Susilo et al., 2009). To identify criteria for selection these should be confirmed using more diverse of genetic background of CPB resistance that expression of the characteristics can be confirmed as genetic expression. 


\section{MATERIALS AND METHODS}

Plant materials for this study were 25 cocoa (Theobroma cacao L.) clones which mostly be exploratory collected through cocoa farms in Indonesia based on CPB resistance (Table 1). The clones were field-tested in Central Sulawesi for evaluating the response to $\mathrm{CPB}$ infestation in a randomized complete block design with 3 blocks as replication; each plot consisted of 4-6 sidegrafted trees. Evaluation for CPB resistance were based on the parameters of the percentage of unextractable bean, the number of larvae entry holes, the number of larvae entry holes pass through sclerotic layer and the number of larvae exit holes. Based on the parameter the tested clones were grouped into five groups of resistance, namely resistant, moderate resistant, moderate susceptible, susceptible and highly susceptible (Susilo et al., 2009). All of the tested clones were also assessed for genetic background using simple sequence repeat (SSR) markers that were confirmed all of the tested clones genetically different (Susilo et al., 2013).

Pod samples for assessing the characteristics were detached from the selected tree on each plot through four blocks of replication. The pod samples were categorized based on the maturity, namely $3.0 ; 3.5$; and 4.0 months. Tissue of the detached pod $\left( \pm 1 \mathrm{~cm}^{3}\right)$ then fixed in $70 \%$ alcohol before being shipped for analysis in Genetics Laboratory of Gadjah Mada University Yogyakarta.

A laboratory work was carried out to confirm expressions of the pod characteristics following the method reported in the previous study (Susilo et al., 2007). Sample of tissue then treated using microchemical analysis to identify the appearance of trichomes at upper layer cocoa mesocarp, the granules of tannin distributed through mesocarp and lignification at sclerotic layer. Each pod sample was excised at three different positions of pod, namely furrow, primary furrow and secondary furrow then transverse-sectioned for microchemical treatment, namely chemical treatment for microscopic analysis.

Procedure on characterization of the granules of tannin distributed through mesocarp follows the micro chemical treatment in which the tissue was prepared using micro technique approach. The excised tissue of mesocarp were cross-sectioned using a sliding microtome at the thickness of $20-40 \mu \mathrm{m}$ then dipped in the mix solution of $2 \mathrm{~g}$ ferrous sulfate, $10 \mathrm{~mL}$ formalin and $90 \mathrm{~mL}$ aquadest sterile for 24-48 hours. After the chemical treatment, the sample tissues were placed on deck glass with a drop of glycerin for microscopic visualization in magnification of 250 times. By using a photomicrographs, the granule of tannin can be recorded by counting the number per specified area. It was also altogether enable be evaluated the appearance of trichome at the upper layer of epidermis tissue (Susilo et al., 2007).

Chemical treatment for lignification, the cross sectioned tissue were dipped in alcohol $70 \%$ and then colored using a solution of $2 \mathrm{~g}$ phloroglucin and $100 \mathrm{~mL}$ alcohol $95 \%$ for 15 minutes. After colorization the tissue were rinsed using $25 \%$ of $\mathrm{HCl}$ for 5 minutes then placed on a deck glass for microscopic analysis. Evaluation of lignification used a photomicrograph in magnification of 400 times. The lignified tissue performed red color which then can be measured for the thickness of the layer and described compactness of the non-lignified tissue. Considering tissue of young pod was not so lignified then measurement of thickness and number of channels were just performed in mature pods. 
Table 1. Cocoa clones established in Central Sulawesi used for evaluation the CPB resistance

\begin{tabular}{|c|c|c|c|}
\hline KW series & Clone & Origin & Response to CPB field infestation $\left.{ }^{*}\right)$ \\
\hline KW 264 & KPC 1 & $\begin{array}{l}\text { Local clone explored from java criollo population } \\
\text { in East Java }\end{array}$ & Moderate susceptible \\
\hline KW 265 & KPC 2 & $\begin{array}{l}\text { Local clone explored from java criollo population } \\
\text { in East Java }\end{array}$ & Susceptible \\
\hline KW 162 & Sul-01 & Local clone & Susceptible \\
\hline KW 163 & Sul-02 & Local clone & Moderate susceptible \\
\hline KW 165 & Bal 209 & Introduced clone & Susceptible \\
\hline KW 571 & ARDACIAR 25 & Local clone explored in Central Sulawesi & Moderate susceptible \\
\hline KW 524 & Toli-toli & Local clone explored in Central Sulawesi & Moderate susceptible \\
\hline KW 525 & Nob 1 & Local clone explored in East Kalimantan & Moderate susceptible \\
\hline KW 527 & Nob 3 & Local clone explored in East Kalimantan & Moderate susceptible \\
\hline KW 570 & ARDACIAR 10 & Local clone explored in South Sulawesi & Resistant \\
\hline KW 516 & $\mathrm{Paba} / \mathrm{VIII} / 78 \mathrm{~B} / 2$ & Local clone explored in North Sumatra & Highly susceptible \\
\hline KW 30 & ICCRI 03 & Recommended clone selected from breeding population & Moderate resistant \\
\hline KW 216 & Pengawu & Local clone explored in Central Sulawesi & Moderate susceptible \\
\hline KW 396 & $\mathrm{Na} 32$ & Introduced clone & Moderate susceptible \\
\hline KW 397 & $\mathrm{Na} 33$ & Introduced clone & Resistant \\
\hline KW 529 & HF 3 & Local clone explored in East Kalimantan & Moderate susceptible \\
\hline KW 528 & HF 2 & Local clone explored in East Kalimantan & Moderate susceptible \\
\hline KW 403 & Pound 7 & Introduced clone & Susceptible \\
\hline KW 422 & KKM 22 & Introduced clone & Moderate resistant \\
\hline KW 48 & ICCRI 04 & Recommended clone selected from breeding population & Susceptible \\
\hline KW 566 & $\mathrm{Paba} / \mathrm{V} / 81 \mathrm{~L} / 1$ & Local clone explored in North Sumatra & Resistant \\
\hline KW 564 & $\mathrm{Paba} / \mathrm{IX} / 90 \mathrm{O} / 2$ & Local clone explored in North Sumatra & Highly susceptible \\
\hline KW 572 & ARDACIAR 26 & Local clone explored in Central Sulawesi & Moderate resistant \\
\hline KW 215 & Sausu Piore & Local clone explored in Central Sulawesi & Moderate susceptible \\
\hline KW 514 & $\mathrm{Paba} / \mathrm{I} / \mathrm{Pbrk}$ & Local clone explored in North Sumatra & Moderate resistant \\
\hline
\end{tabular}

Further analysis was also carried out to identify histological characteristics of the lignified tissue. Laboratory works for this analysis was carried out at the Histology Laboratory, School of Biological Science the University of Reading, United Kingdom follow the method of Steven (1999). For this study, only a few number of tested clones were selected which representing the susceptible and resistance, namely KW 516 (very susceptible), ARDACIAR 10 and KW 566 (resistant). Data analysis based on the qualitative performance of the lignified tissue.

Variance analysis was performed for quantitative data at $\alpha=5 \%$ then follow up by canonical analysis using SAS 9.1 Program. To support correlation between field study and the laboratory study some of data reported by Susilo et al. were used (2009). The covariance of genetic and phenotypic were classified as low $(0 \%-\leq 25 \%)$, moderate $(25 \%-\leq 50 \%)$ and high $(50 \%-\leq 75 \%)$ (Moedjiono \& Mejaya, 1994).

\section{RESULTS AND DISCUSSION}

Analysis of variance shows a significant effect of cocoa clones to the variables of pod characteristics related to $\mathrm{CPB}$ resistance at the different level of pod maturity

PELITA PERKEBUNAN, Volume 31, Number 1, Edition April 2015 
(Table 2) that could be confirmed that the characteristics of pod are genetic expression of the tested clones. Higher value of coefficient variation was identified for trichome density $(>30 \%)$ indicating the trichomes might not be distributed evenly through the surface of pod. This result also performed any differences of the characteristics in different pod maturity as was reported in the previous study wherein the characteristics were maximally expressed during 3.0-4.0 months of pod maturity (Susilo et al., 2009).

The percentage of unextractable beans was vary among clones in the range of 35.8$91.7 \%$ which performing the range of genetic variation of CPB resistance among tested clones. Furthermore it could be expected that the clone which having lower number of that percentage performing more resis- tance to CPB. ARDACIAR 10 of the clone which have lowest value of the percentage $(35.78 \%)$ would be the most resistant in contrast to the clone of KW 516 and KW 564 which have highest value of $83.2 \%$ and $91.7 \%$ respectively would be most susceptible (Table 3). A positive correlation was confirmed between the percentage of unextractable beans with the number of larvae exit holes $\left(\mathrm{r}=0.62^{*}\right)$ and indirectly correlated with the number of entry holes as the number of exit holes positively correlated with the ratio of the number of exit holes to the number of entry holes $(r=$ $\left.0.59^{*}\right)$. This result confirms the severity damage due to CPB depend on how many larvae are able to complete its life cycle inside the pod which be performed with the number of larvae exit holes.

Table 2. Mean square of variance analysis the pod characteristics related to CPB resistance

\begin{tabular}{|c|c|c|c|c|}
\hline \multirow{2}{*}{ Sources of variation } & \multirow{2}{*}{ Degree of freedom } & \multicolumn{3}{|c|}{ Pod age } \\
\hline & & 3.0 months & 3.5 months & 4.0 months \\
\hline \multicolumn{5}{|c|}{ Thickness of sclerotic layer at primary furrow $(\mathrm{PF}), \mathrm{mm}$} \\
\hline Clone & 24 & $0.13^{\mathrm{ns}}$ & $0.21 *$ & $0.35 *$ \\
\hline Block & 3 & 0.06 ns & 0.13 ns & $0.03 \mathrm{~ns}$ \\
\hline Error & 72 & 0.05 & 0.06 & 0.10 \\
\hline $\mathrm{CV}(\%)$ & & 26.55 & 25.95 & 30.82 \\
\hline \multicolumn{5}{|c|}{ Thickness of sclerotic layer at the segment between primary furrow $(\mathrm{F}), \mathrm{mm}$} \\
\hline Clone & 24 & $0.02 *$ & $0.03 *$ & $0.04 *$ \\
\hline Block & 3 & 0.01 ns & 0.002 ns & 0.001 ns \\
\hline Error & 72 & 0.004 & 0.003 & 0.003 \\
\hline $\mathrm{CV}(\%)$ & & 18.78 & 15.08 & 12.72 \\
\hline \multicolumn{5}{|c|}{ Number of tannin granules through mesocarp $(\mathrm{Tn})$ per $\mathrm{mm}^{2}$ of unit area } \\
\hline Clone & 24 & $0.38 *$ & $0.26 *$ & $0.30 *$ \\
\hline Block & 3 & 0.03 ns & 0.07 ns & 0.04 ns \\
\hline Error & 72 & 0.07 & 0.05 & 0.04 \\
\hline CV $(\%)$ & & 18.69 & 20.24 & 19.93 \\
\hline \multicolumn{5}{|c|}{ Number of trichomes (Tr) per mm } \\
\hline Clone & 24 & $19.42 *$ & $16.32 *$ & $16.56 *$ \\
\hline Block & 3 & 0.29 ns & 0.18 ns & $0.81 \mathrm{~ns}$ \\
\hline Error & 72 & 2.92 & 1.56 & 3.26 \\
\hline $\mathrm{CV}(\%)$ & & 37.22 & 33.21 & 55.20 \\
\hline
\end{tabular}

PELITA PERKEBUNAN, Volume 31, Number 1, Edition April 2015 
Table 3. Mean of the variables correspond to CPB resistance of cocoa clones tested in Central Sulawesi

\begin{tabular}{|c|c|c|c|c|c|c|}
\hline $\begin{array}{l}\text { KW } \\
\text { series }\end{array}$ & Clone & $\begin{array}{l}\text { Unextract- } \\
\text { able beans, } \%{ }^{1)}\end{array}$ & $\begin{array}{l}\text { No. of entry } \\
\text { holes }^{2)}\end{array}$ & $\begin{array}{l}\text { No.of entry } \\
\text { holes through } \\
\text { sclerotic layer }\end{array}$ & $\begin{array}{l}\text { No. of exit } \\
\text { holes }\end{array}$ & $\begin{array}{l}\text { Ratio exit holes } \\
\text { to entry holes }\end{array}$ \\
\hline KW 264 & KPC 01 & $64.26 \mathrm{MS}$ & $30.78 \mathrm{a}$ & $22.89 \mathrm{ab}$ & 5.36 abcdef & $0.21 \mathrm{def}$ \\
\hline KW 265 & KPC 02 & $76.95 \mathrm{~S}$ & 17.68 bcde & $12.77 \mathrm{cdef}$ & $7.04 \mathrm{a}$ & $0.51 \mathrm{ab}$ \\
\hline KW 162 & Sulawesi 01 & $72.97 \mathrm{~S}$ & $22.52 \mathrm{abcd}$ & $16.36 \mathrm{abcd}$ & 5.51 abcde & 0.26 cdef \\
\hline KW 163 & Sulawesi 02 & $66.16 \mathrm{MS}$ & $14.21 \mathrm{bcde}$ & $10.49 \mathrm{cdef}$ & $7.00 \mathrm{a}$ & $0.49 \mathrm{ab}$ \\
\hline KW 165 & Bal 209 & $69.45 \mathrm{~S}$ & $25.13 \mathrm{abc}$ & $18.73 \mathrm{abc}$ & $2.38 \mathrm{fg}$ & 0.09 ef \\
\hline KW 571 & ARDACIAR 25 & $63.01 \mathrm{MS}$ & $12.87 \mathrm{de}$ & $8.03 \mathrm{def}$ & 3.38 bcdefg & $0.26 \mathrm{cdef}$ \\
\hline KW 524 & Toli-toli & $60.92 \mathrm{MS}$ & 19.90 abcde & $14.12 \mathrm{cdef}$ & 5.51 abcde & 0.30 bcde \\
\hline KW 525 & Nob 1 & $67.74 \mathrm{MS}$ & $18.38 \mathrm{bcde}$ & $14.45 \mathrm{cdef}$ & 4.41 abcdef & $0.26 \mathrm{cdef}$ \\
\hline KW 527 & Nob 3 & $66.50 \mathrm{MS}$ & $31.01 \mathrm{a}$ & $24.22 \mathrm{a}$ & $2.81 \mathrm{defg}$ & $0.09 \mathrm{f}$ \\
\hline KW 570 & ARDACIAR 10 & $35.78 \mathrm{R}$ & $11.44 \mathrm{de}$ & $6.69 \mathrm{ef}$ & $2.47 \mathrm{efg}$ & $0.22 \mathrm{def}$ \\
\hline KW 516 & $\mathrm{Paba} / \mathrm{VIII} / 78 \mathrm{~B} / 2$ & 83.19 HS & $25.90 \mathrm{ab}$ & $18.72 \mathrm{abc}$ & $6.41 \mathrm{ab}$ & $0.25 \mathrm{cdef}$ \\
\hline KW 30 & ICCRI 03 & 48.37 MR & $10.55 \mathrm{de}$ & $7.80 \mathrm{def}$ & $2.81 \mathrm{defg}$ & $0.31 \mathrm{bcd}$ \\
\hline KW 216 & Pengawu & $62.95 \mathrm{MS}$ & 17.95 bcde & $13.55 \mathrm{cdef}$ & 3.43 bcdefg & $0.19 \mathrm{def}$ \\
\hline KW 396 & $\mathrm{Na} 32$ & $62.43 \mathrm{MS}$ & 14.65 bcde & $11.19 \mathrm{cdef}$ & 4.71 abcdef & $0.32 \mathrm{bcd}$ \\
\hline KW 397 & $\mathrm{Na} 33$ & $40.29 \mathrm{R}$ & $10.21 \mathrm{e}$ & 6.93 ef & $1.03 \mathrm{~g}$ & $0.13 \mathrm{def}$ \\
\hline KW 529 & HF 3 & $65.20 \mathrm{MS}$ & 14.35 bcde & $8.56 \mathrm{def}$ & $3.26 \mathrm{cdefg}$ & $0.22 \mathrm{def}$ \\
\hline KW 528 & HF 2 & 64.74 MS & 15.82 bcde & $11.44 \mathrm{cdef}$ & 5.01 abcdef & $0.33 \mathrm{bcd}$ \\
\hline KW 403 & Pound 7 & $69.07 \mathrm{~S}$ & 20.14 abcde & $15.18 \mathrm{cdef}$ & $2.73 \mathrm{defg}$ & $0.25 \mathrm{cdef}$ \\
\hline KW 422 & KKM 22 & $51.01 \mathrm{MS}$ & $13.47 \mathrm{cde}$ & $7.82 \mathrm{def}$ & $5.65 \mathrm{abcd}$ & $0.45 \mathrm{abc}$ \\
\hline KW 48 & ICCRI 04 & $75.50 \mathrm{~S}$ & $10.85 \mathrm{de}$ & $8.06 \mathrm{def}$ & 5.22 abcdef & $0.48 \mathrm{ab}$ \\
\hline KW 566 & $\mathrm{Paba} / \mathrm{V} / 81 \mathrm{~L} / 1$ & $42.12 \mathrm{R}$ & $25.80 \mathrm{ab}$ & $15.22 \mathrm{bcde}$ & $2.55 \mathrm{efg}$ & $0.09 \mathrm{f}$ \\
\hline KW 564 & $\mathrm{Paba} / \mathrm{IX} / 90 \mathrm{O} / 2$ & $91.72 \mathrm{HS}$ & $11.09 \mathrm{de}$ & $9.52 \mathrm{def}$ & $5.88 \mathrm{abc}$ & $0.55 \mathrm{a}$ \\
\hline KW 572 & ARDACIAR 26 & $44.62 \mathrm{MR}$ & $11.71 \mathrm{de}$ & $6.41 \mathrm{f}$ & $3.33 \mathrm{cdefg}$ & $0.33 \mathrm{bcd}$ \\
\hline KW 215 & Sausu Piore & $62.02 \mathrm{MS}$ & 19.73 abcde & $13.03 \mathrm{cdef}$ & 3.97 bcdefg & $0.20 \mathrm{def}$ \\
\hline KW 514 & $\mathrm{Paba} / \mathrm{I} / \mathrm{Pbrk}$ & $53.41 \mathrm{MR}$ & 21.50 abcde & $13.41 \mathrm{cdef}$ & 3.64 bcdefg & $0.16 \mathrm{def}$ \\
\hline
\end{tabular}

\section{Relationship Between Resistant Charac- teristics}

Analysis of canonical correlation showed a positive association between the number of entry holes and number of entry holes through sclerotic layer with the thickness of sclerotic layer at the secondary furrow at the different level of pod maturity. In contrast, the ratio of the number of exit holes to the number of entry holes was negatively associated with the thickness (Table 4). Further analysis support the result that the thickness of sclerotic layer at the secondary furrow performed a higher value of the coefficient in association with the variables of canonical for pod characteristics $(0.59 ; 0.55$; 0.43 ) and the variables of canonical for $\mathrm{CPB}$ resistance $(0.54 ; 0.51 ; 0.39)$ (Table 5). Therefore it could be concluded that the thickness of sclerotic layer at the secondary furrow as the representative characteristics related to $\mathrm{CPB}$ resistance. However, association between the thicknes with the variable of $\mathrm{CPB}$ 
resistance would not be interpreted as linier combination but just performing a higher contribution of the characteristics on CPB resistance. The sclerotic layer would play role on buffering larvae movement into the placental area for feeding but it is still unclear mechanism of the layer as physical or chemical barrier. Alonzo-Díaz et al. (2008) reported an extracted-tannin of some plants which was able to suppress larvae movement of Trycho-strongylus colubiformis. Lignin is the second compound of plant tissue after cellulose contributing on plant structure and resistance to pest and disease (Weiting Ni \& Jung, 1998).

Mean differences of those characteristic were different among tested clones in which the more resistant clones performed higher value of the thickness of sclerotic layer at secondary furrow but not for others characteristics (Figure 1). Measurement of the thickness is an approach how to quantify the lignification at the sclerotic layer. However, the most resistant clone of ARDACIAR 10 performed similar of the thickness with the susceptible clones. Qualitative assessment of the lignification at sclerotic layer showed a significant differences of the lignification performance between the resistant clones of ARDACIAR 10 and KW 397 and the susceptible clones of ICCRI 04, KW 516 and KW 564 in which the resistant clones performed more intensive and more compact of the lignifiedtissues compared to the susceptible clones (Figure 2). Xi Liu et al. (2011) also reported the lignin content of the resistant cotton to wilt fungus of Verticillium dahlia higher than of the susceptible plant that lignin was the important compound on cotton resistance. Histological analysis of the lignified tissue detected more cells on the resistant clones (ARDACIAR 10 and KW 397) differentiated to woody tissue indicating a physical barrier of the layer to larvae movement (Figure 3).

Table 4. Canonical correlation among the characteristics of CPB resistance and the variables of plant's resistance to CPB

\begin{tabular}{|c|c|c|c|c|c|}
\hline $\begin{array}{l}\text { Pod } \\
\left.\text { characteristics }{ }^{*}\right)\end{array}$ & $\begin{array}{l}\text { Pod maturity, } \\
\text { month }\end{array}$ & $\begin{array}{c}\text { No. of } \\
\text { entry holes }\end{array}$ & $\begin{array}{l}\text { No. of entry } \\
\text { holes through } \\
\text { sclerotic layer }\end{array}$ & $\begin{array}{l}\text { No. of exit } \\
\text { holes }\end{array}$ & $\begin{array}{c}\text { Ratio between } \\
\text { exit holes } \\
\text { to entry holes }\end{array}$ \\
\hline $\mathrm{PF}$ & 3.0 & 0.20 & 0.21 & -0.11 &,-0.27 \\
\hline PF & 3.5 & 0.17 & 0.17 & -0.15 & I $\quad-0.31$ \\
\hline $\mathrm{PF}$ & 4.0 & 0.18 & -0.14 & -0.21 & $\begin{array}{ll}\text { I } & -0.36\end{array}$ \\
\hline F & 3.0 & $-\overline{0.62}$ & 0.64 & -0.01 & -0.39 \\
\hline $\mathrm{F}$ & 3.5 & $\quad 0.56$ & $0.55 \quad$ ' & -0.01 & $\begin{array}{lll}1 & & \\
1 & -0.35 & 1\end{array}$ \\
\hline $\mathrm{F}$ & 4.0 & $\checkmark-0.45$ & $0.48,->$ & -0.02 & $'-0.29, '$ \\
\hline Tn & 3.0 & $-0.09-$ & $-{ }_{-0}^{-0.05}$ & -0.07 & 0.07 \\
\hline Tn & 3.5 & 0.02 & 0.06 & -0.05 & 0.01 \\
\hline Tn & 4.0 & -0.08 & -0.02 & 0.08 & 0.17 \\
\hline $\operatorname{Tr}$ & 3.0 & 0.29 & 0.45 & 0.35 & 0.15 \\
\hline $\operatorname{Tr}$ & 3.5 & 0.17 & 0.33 & 0.14 & 0.08 \\
\hline $\operatorname{Tr}$ & 4.0 & 0.15 & 0.32 & 0.25 & 0.13 \\
\hline
\end{tabular}

Notes: $\quad \mathrm{PF}=$ thickness of sclerotic layer at primary furrow $(\mathrm{mm}) ; \mathrm{F}=$ thickness of sclerotic layer at the secondary furrow $(\mathrm{mm}) ; \mathrm{Tn}=$ number of tannin granules per $\mathrm{mm}^{2} ; \mathrm{Tr}=$ number of trichomes per $\mathrm{mm}$, numbers inside the ellips-circles indicate higher value of canonical coefficient. 


\section{Genetic Resistant Characteristics}

Thickness at furrow on 3.0, 3.5 and 4.0 months of pod maturity was also analyzed performing high value of broad-sense heritability i.e. $0.75 ; 0.89$ and 0.92 respectively (Table 6) that confirmed the thickness as genetic expression of the tested clones. This was also supported by small difference in genetic coefficient of variation to phenotypic coefficient of variation for the thickness at the secondary furrow. A phenomenon of genotype by environment interaction was reported on yam resistance to anthracnose however genetic factor was more influenced on the resistance (Egesi et al., 2009). Further analysis show a low classification of genetic coefficient of variation $(\leq 25 \%)$ of the thickness at the secondary furrow indicating a low variability of $\mathrm{CPB}$ resistance from this study. Study on the analysis of the quantitative trait

Table 5. Correlation among the characteristics of $\mathrm{CPB}$ resistance with their canonical variables [A1] and the canonical variables of plant's resistance to CPB infestation [B1]

\begin{tabular}{lll}
\hline Variables $^{*}$ & {$[\mathrm{~A} 1]$} & {$[\mathrm{B} 1]$} \\
\hline PF-3.0 & 0.12 & 0.11 \\
PF-3.5 & 0.07 & 0.07 \\
PF-4.0 & 0.09 & 0.51 \\
F-3.0 & 0.55 & 0.39 \\
F-3.5 & -0.01 & -0.09 \\
F-4.0 & 0.09 & -0.04 \\
Tn-3.0 & -0.04 & 0.26 \\
Tn-3.5 & 0.29 & 0.19 \\
Tn-4.0 & 0.21 & 0.12 \\
Tr-3.0 & 0.13 & 0.09 \\
Tr-3.5 & ${ }^{*}$ Notation of variables refer to Table 4, numbers in the ellips circle indicate a higher value of canocial correlation \\
Tr-4.0 &
\end{tabular}

Table 6. Genetic parameters of pod characteristics related CPB resistance among the tested clones

\begin{tabular}{|c|c|c|c|c|c|}
\hline $\begin{array}{l}\text { Pod } \\
\left.\text { characteristics }{ }^{*}\right)\end{array}$ & $\begin{array}{l}\text { Pod maturity, } \\
\text { month }\end{array}$ & $\mathrm{h}_{\mathrm{bs}}^{2}$ & PCV (\%) & GCV $(\%)$ & Mean \\
\hline PF & 3.0 & 0.38 & 16.43 & 10.06 & 0.86 \\
\hline $\mathrm{PF}$ & 3.5 & 0.60 & 20.84 & 16.14 & 0.93 \\
\hline PF & 4.0 & 0.60 & 23.81 & 18.44 & 1.05 \\
\hline $\mathrm{F}$ & 3.0 & 0.75 & 17.60 & 15.24 & 0.36 \\
\hline $\mathrm{F}$ & 3.5 & 0.89 & 21.19 & 19.98 & 0.39 \\
\hline $\mathrm{F}$ & 4.0 & 0.92 & 22.72 & 21.78 & 0.42 \\
\hline $\mathrm{Tn}$ & 3.0 & 0.77 & 20.09 & 17.68 & 1.39 \\
\hline $\mathrm{Tn}$ & 3.5 & 0.76 & 20.47 & 17.87 & 1.12 \\
\hline $\mathrm{Tn}$ & 4.0 & 0.85 & 25.34 & 23.31 & 1.01 \\
\hline $\operatorname{Tr}$ & 3.0 & 0.82 & 44.25 & 40.14 & 4.59 \\
\hline $\operatorname{Tr}$ & 3.5 & 0.89 & 51.15 & 48.38 & 3.76 \\
\hline $\operatorname{Tr}$ & 4.0 & 0.75 & 55.79 & 48.47 & 3.27 \\
\hline
\end{tabular}

PELITA PERKEBUNAN, Volume 31, Number 1, Edition April 2015 

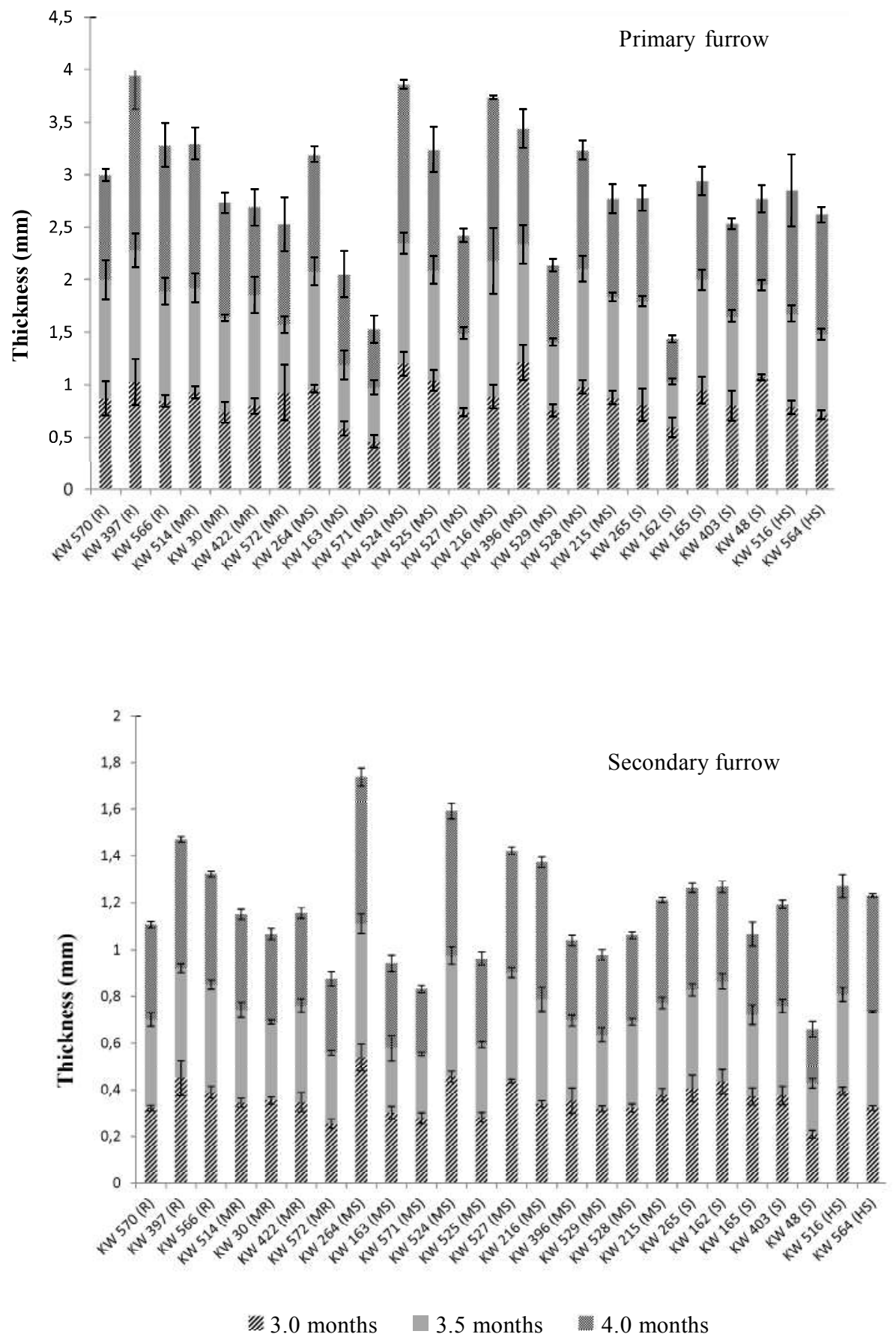

Figure 1. Sclerotic layer thickness at primary furrow (top) and secondary furrow (below) of the tested clones which perform different response to CPB resistance (Bars indicate standard deviation of mean) 

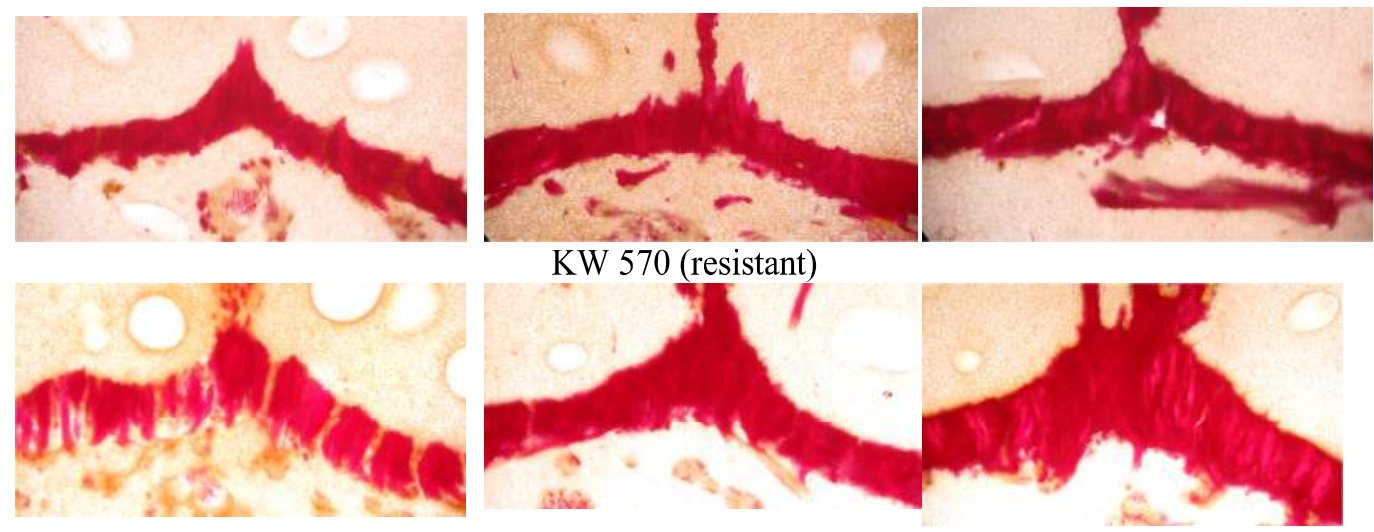

KW 397 (resistant)
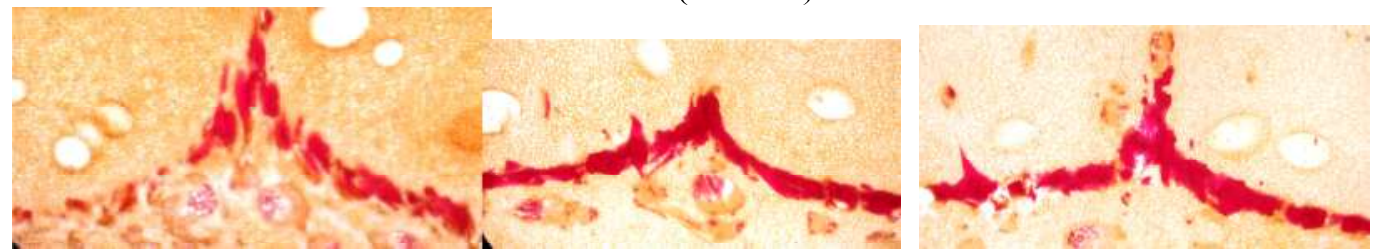

ICCRI 04 (susceptible)
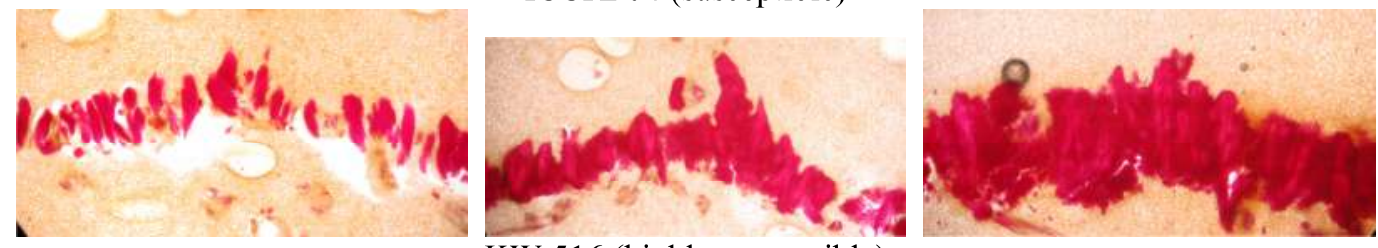

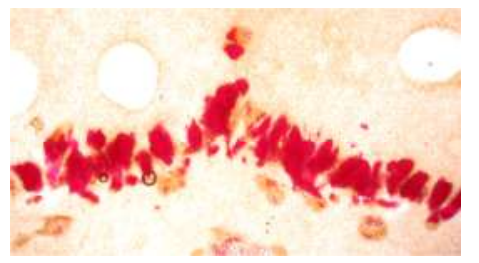

3.0 months
KW 516 (highly susceptible)

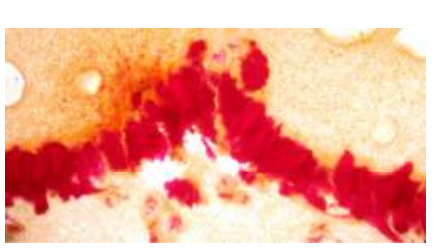

KW 564 (highly susceptible)

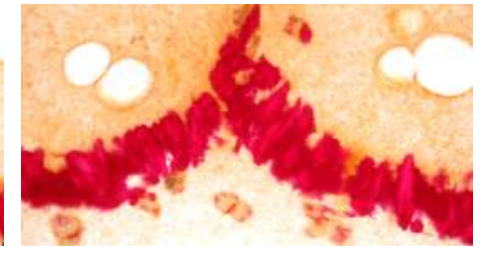

4.0 months

Figure 2. Comparison in lignification at the sclerotic layer of five cocoa clones having difference on CPB resistance at $400 \mathrm{X}$ magnification 

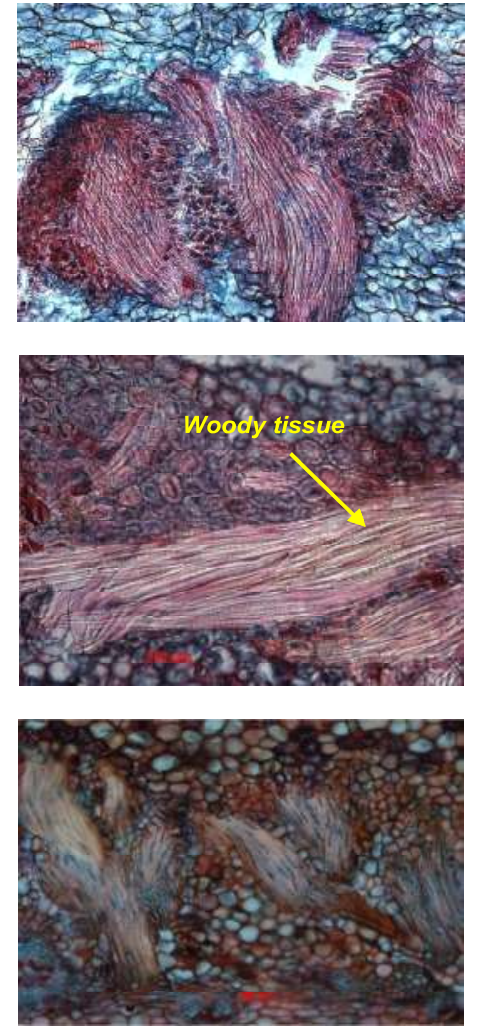

3.0 months

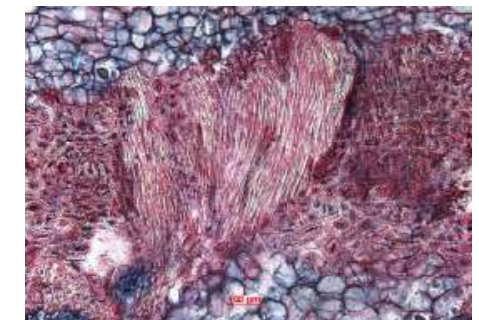

KW 516 (highly susceptible)

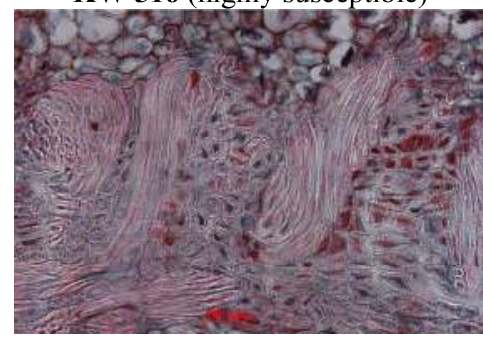

KW 566 (resistant)

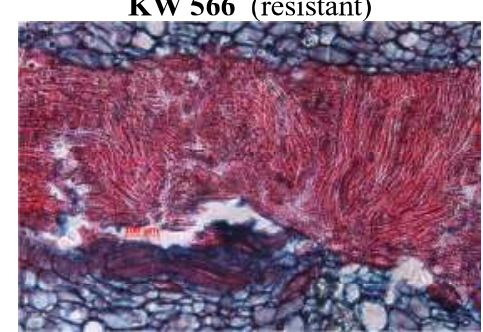

ARDACIAR 10 (resistant)

3.5 months
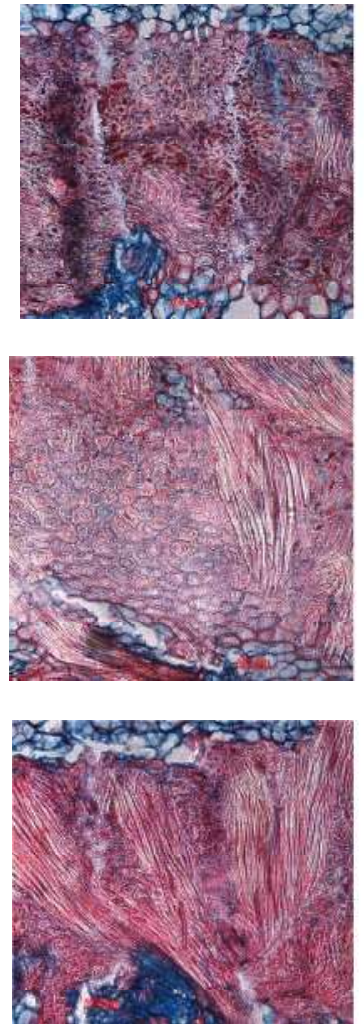

4.0 months

Figure 3. Histological comparison of the lignified sclerotic layer of three cocoa clones difference on CPB resistance at 200X magnification

locy (QTL) for lignin synthesis identified genes controlling on monolignol biosynthesis and polymerization (Chavigneau et al., 2012).

This result showed lignification at sclerotic layer as part of pod characteristics which is possible to be used as criteria for selection on CPB resistance. For further implementation of the lignification analysis it should be simplify the assessment method as lignification have to be evaluated using very complicated method that is not easy to be implemented for large number of cocoa genotypes in term of selection process. Further study have to be focused on the assessment of morphological characteristics of pod related to the lignification that assessment of the criteria selection will be more simple to be carried out in speeding up selection process.

\section{CONCLUSION}

1. The exploratory selected cocoa clones performed difference in the response to CPB infestation in which percentage of unextractable beans positively correlated with the number of larvae exit holes. All of the assessed characteristics of pod related to CPB resistance were significantly affected by clone factor confirming any genetic variation of the resistance among tested clones.

2. Lignification at sclerotic layer represented by the thickness at the secondary furrow on 3.0, 3.5 and 4.0 months of pod maturity performed higher portion of its contribution to represent resistant characteristics. This thickness positively 
associated with the number of entry holes and the number of entry holes through sclerotic layer and negatively associated with ratio of the number of exit holes to the number of entry holes.

3. The thickness of sclerotic layer at the secondary furrow in $3.0 ; 3.5$ and 4.0 months of pod maturity are genetic expression as having high value of broad-sense heritability, namely $0.75,0.89$ and 0.92 , respectively.

\section{Acknowledgements}

The authors wish to thanks Director of Indonesian Coffee and Cocoa Research Institute (ICCRI) for permitting publishing this paper. Thanks also dedicated to ACIAR Management on supporting this research budget through ACIAR project SMAR/ 2005/074 and to Cocoa Research United Kingdom (CRUK) on supporting funding for histological analysis at the University of Reading under supervision Prof. Paul Hadley and Dr. Paul Hatcher.

\section{REFFERENCES}

Alonzo-Díaz, M.A.; J.F.J. Torres-Acosta; C.A. Sandoval-Castro; C. CapetilloLeal; S. Brunet \& H. Hoste (2008). Effect of four tropical tanniniferous plant extracts on the inhibition of larval migration and the exsheathment process of Trychostrongylus colubiformis infective stage. Veterinary Parasitology, 153, 187-192.

Azhar, I. (2000). Measuring ovipositional pre-ference of the cocoa pod borer, Conopomorpha cramerella (Lepidoptera: Gracillariidae) to various cocoa clones. pp. 57-59. In: C.L. Bong, C.H. Lee. \& F.S. Shari (Eds.). Proceedings of INCOPED $3^{\text {rd }}$ International Seminar. Malaysian Cocoa Board.

Chavigneau, H.; N. Goué; S. Delaunay; A. Courtial; L. Jouanin; M. Reymond; V. Méchin
\& Y. Barrière (2012). QTL for floral stem lignin content and degradability in three recombinant inbred line (RIL) progenies of Arabidopsis thaliana and search for candidate genes involved in cell wall biosynthesis and degradability. Open Journal of Genetics, 2, 7-30.

Egesi, C.N.; T.J. Onyeka \& R. Asiedu (2009). Environmental stability of resistance to anthracnose and virus diseases of water yam (Dioscorea alata). African Journal of Agricultural Research, 4, 113-118.

Flood, J.; D. Guest; K.A. Holmes; P. Keane; B. Padi \& E. Sulistyowati (2004). Cocoa under attack. pp. 33-53. In: Flood \& R. Murphy (Eds.). Cocoa Futures: a Source Book of Some Important Issues Confronting the Cocoa Industry. CABI Commodities, Colombia.

Li Xu; Longfu Zhu; Lili Tu; Linlin Liu; Daojun Yuan; Li Jin; Lu Long \& Xianlong Zhang (2011). Lignin metabolism has a central role in the resistance of cotton to the wilt fungus Verticillium dahliae as revealed by RNA-Seqdependent transcriptional analysis and histochemistry. Journal Experimental Botany, 62, 5607-5621.

McMahon; P.A. Iswanto; A.W. Susilo; E. Sulistyowati; A. Wahab; M. Imron; A. Purwantara; E. Mufrihati; V.S. Dewi; S. Lambert; D. Guest \& P. Keane (2009). On-farm selection for quality and resistance to pest/diseases of cocoa in Sulawesi: (i) performance of selections against cocoa pod borer, Conopomorpha cramerella. International Journal of Pest Management, 55, 325-337.

Moedjiono \& J. Mejaya (1994). Variabilitas genetik beberapa karakter plasma nutfah jagung koleksi Ballitan Malang. Zuriat, 5, 27-32.

Sulistyowati, E. \& S. Wiryadiputra (2008). Perkembangan teknik pengendalian terpadu hama penggerek buah kakao (Conopomorpha cramerella).pp. 109-129. In: T. Wahyudi, S. Abdoellah, A.A. Prawoto, J.B. Baon, S. Mawardi \& Sri-Mulato 
(Eds.). Prosiding Simposium Kakao 2008, Denpasar, 28-30 Oktober 2008.

Susilo, A.W.; E. Sulistyowati \& E. Mufrihati (2004). Eksplorasi genotipe kakao tahan hama penggerek buah kakao (Conopomorpha cramerella Snell.). Pelita Perkebunan, 20, 1-12.

Susilo, A.W.; E. Sulistyowati \& E. Mufrihati (2005). Seleksi klon unggul kakao tahan hama penggerek buah kakao (Conopomorpha cramerella Snell.). Laporan Akhir Tahun Pusat Penelitian Kopi dan Kakao Indonesia (tidak dipublikasikan).

Susilo, A.W.; E. Sulistyowaty; E. Mufrihati; A. Wahab; P. McMahon; A. Purwantara \& A. Iswanto (2006). Selection for improved quality and resistance of Phytophthora pod rot, cocoa pod borer, and vascular streak dieback on cocoa in Indonesia. Annual Progress Report ACIAR PHT/2000/102 (unpublished).

Susilo, A.W.; W. Mangoendidjojo \& Witjaksono (2007). Hubungan karakteristik jaringan kulit buah beberapa klon kakao (Theobroma cacao L.) dengan sifat ketahanan hama penggerek buah kakao. Pelita Perkebunan, 23, 159-175.

Susilo A.W.; W. Mangoendidjojo; Witjaksono \& S. Mawardi (2009). Pengaruh perkembangan umur buah beberapa klon kakao terhadap keragaan sifat ketahanan hama penggerek buah kakao. Pelita Perkebunan, 25, 1-11.
Susilo, A.W.; I. Anita-Sari; Sobadi; I. Ketut Suwitra \& Nurlia (2012). Stabilitas dayahasil klon-klon harapan kakao (Theobroma cacao L.) tahan hama penggerek buah kakao (Conopomorpha cramerella Snell.). Pelita Perkebunan, $28,123-135$.

Susilo, A.W.; D. Zhang \& L. Motilal (2013). Assesing genetic diversity cocoa (Theobroma cacao L.) collection resistance to cocoa pod borer using simple sequence repeat marker. Pelita Perkebunan, 29, 82-92.

Steven, E.R. (1999). Plant Microtechnique and Microscopy. Biological Facility University of California Berkeley, New York, Oxford, Oxford University Press.

Weiting Ni \& H.J.G. Jung (1998). Lignification of plant cell walls: Impact of genetic manipulation. Proceeding National Academy Science USA, 95,12742-12743.

Wardojo, S. (1980). The cocoa pod borer-A major hindrance to cocoa development. Indonesian Agricultural Research and Development Journal, 2, 1-4.

$$
* * 0 * *
$$

